\title{
Propolis Research in Russia
}

\author{
Victoria Vladimirovna Fedotova, Dmitry Alexeevich Konovalov*
}

Department of Pharmacognosy, Botany and Technology of Phytopreparations, Pyatigorsk Medical and Pharmaceutical Institute, A Branch of Volgograd State Medical University Ministry of Health of Russian Federation, Pyatigorsk, RUSSIA.

\begin{abstract}
This review presents data on the current propolis research in Russia. The chemical composition, color, aroma and appearance of propolis are influenced by natural and climatic factors, the collection region and the originality of the flora in the collection place. Within Russia, organoleptic, physicochemical and chemical properties of propolis vary considerably. The article provides information on methods for assessing its quality. Propolis is widely used in folk and alternative branches of medicine in Russia. Its antioxidant and antimicrobial properties, as well as the possibility of using extracts on its basis for gastric ulcer, diabetes, periodontitis, radiation disease, gynecological diseases, tuberculosis, anemia, myocardial ischemia and cerebral ischemia, have been established. Propolis is used in the food industry, cosmetology, agriculture and veterinary medicine.
\end{abstract}

Key words: Antibacterial, Antioxidant, Diabetes, Flavonoids, Gastric ulcer, Propolis.

\section{INTRODUCTION}

Propolis is a product of processing resinous substances of a vegetable origin collected by bees from buds, shoots, leaves, bark and stems and in some cases - from herbs and bushes. Propolis is a solid mass of dark gray or brownish brown color with a greenish tint to a brownish-red color and easily soluble in alcohol but hydrophobe. The taste is bitter, burning and astringent with a characteristic fragrant smell. This is the glue that insects use for sealing various cracks in the hive, reducing the lettuce holes in winter, gluing the hangers of the frames, polishing the (honey) comb cells, as well as giving them a greater strength. ${ }^{1}$

The chemical composition, appearance, color and aroma of propolis depend on the natural environment and climatic factors, the collection region and the originality of the flora in the collection place. Thus, propolis, collected in the area with predominant growth of conifers, is shaded green or brown, whereas propolis collected from Populus sp. has a brown-red color. Sometimes, apiaries happen to be located along the roads and the bees then collect bitumen.
In this case, propolis acquires black shades with black veins. ${ }^{2}$

The following plants are used as the main sources for the production of propolis by bees: Black poplar (Populus nigra), species from the genus Willow (Salix sp.) in the southern regions of Russia; Populus balsamifera in Primorye and the Far East; warty birch (Betula pendula); and pubescent birch (Betula pubescens) are used for the collection of resinous substances in Siberia and Central Russia. As the additional resource for the collection of resins, European aspen (Populus tremula) is used. ${ }^{3}$

Propolis of different botanical and geographical origin is distinguished by the content of individual biologically active substances, which can also serve as its markers. Hence, it was established that caffeic acid enters the propolis temperate zone of Russia from the resinous secretions of $P$. nigra, as a rule. Benzoic acid in the studied parts of plants varies and is not detected in all the samples. The petioles of $P$. nigra are the main resource of histidine. The buds of
Submission Date: 11-09-2019; Revision Date: 26-09-2019; Accepted Date: 17-10-2019

DOI: 10.5530/ijper.53.4s.144 Correspondence: Dr. Dmitry Alexeevich Konovalov,

Department of Pharmacognosy and Botany, Pyatigorsk Medical and Pharmaceutical Institute, A Branch of Volgograd State Medical University Ministry of Health of Russian Federation, Pyatigorsk-357532, RUSSIA. Phone: 88793342076 E-mail: d.a.konovalov@ pmedpharm.ru

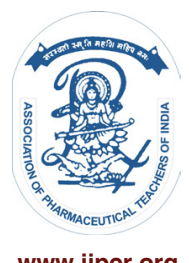

www.ijper.org 
Betula sp. serve as the main source of phenylalanine in the propolis temperate zone of Russia. ${ }^{4}$

\section{Study of the chemical composition of propolis Qualitative analysis}

\section{Phenolic compounds}

The peculiarities of the chemical composition of propolis are due to the phytogeographical and natural environment and climatic features of the collection region. Each plant species accumulates some amount of phenolic compounds, the composition of which depends on the phase of their growth and development. ${ }^{5}$

In temperate latitudes, including a significant territory of Russia, the source of propolis is the plants from the following genera: Poplar (Populus L.) and birch (Betula L.). Propolis contains characteristic phenolic compounds of poplar bud resin: phenolic acids (caffeic and benzoic acids) and their esters, flavones and flavonoids. ${ }^{6}$ The research carried out by Kaigorodov and Suvorova showed significant differences in the content of phenolic acids depending on the type and organ of the following plant sources of the propolis temperate zone: Black poplar (Populus nigra L.), European aspen (P. tremula L.) and warty birch (Betula pendula Roth) [Table 1]. ${ }^{4}$

The results of these studies allowed the authors to conclude that caffeic acid enters propolis from resinous extracts of $P$. nigra, as a rule. The content of benzoic acid in the studied parts of the plants varies and is not found in all the samples. ${ }^{4}$

In the thick extract of propolis from the Moscow region, by High-performance Liquid Chromatography (HPLC) method, cinnamic, coumaric and ferulic acids as well as flavonoids such as pinocembrin, pinostrobin, acacetin, isalpinine, tectochrysin and cumatokillin were identified.

The chemical composition of propolis and the extract prepared on its basis have been studied by gas chromatography with mass-selective detection and HPLC methods. Rutin, apigenin, quercetin, kaempferol, dimethyl kaempferol and caffeic acid have also been identified. ${ }^{8}$

While carrying out comparative studies of various samples of raw materials and a propolis tincture by methods of spectrophotometry and thin-layer chromatography, it was established that the main components of propolis, as in the case of the buds of Populus sp., are flavonoids (pinocembrin, pinostrobin, etc.) and phenylpropanoids (caffeic, ferulic, coumaric acids, etc.). ${ }^{\text {? }}$

\section{Amino acids}

Kaigorodov and Suvorova established that the amino acid content in the plants studied by them is individual for a particular plant species and its organ [Table 2]. ${ }^{4}$

Thus, P. nigra petioles are the main sources of histidine in the propolis of the temperate zone. The buds of $B$. pendula are the main source of phenylalanine. The amino acid profile of propolis can be used to classify its phytogeographical types. ${ }^{4}$

\section{Proteins}

Electrophoresis in polyacrylamide gel is a promising method for the standardization of propolis raw materials and medicines. On the propolis electropherogram and the sources of its collection, protein fractions with a molecular weight of 3000-5000 Da have been found. Lighter protein fractions have been identified in the bud samples of Populus suaveolens, P. nigra, P. balsamifera and $P$. canadensis and also in most propolis samples collected in

\begin{tabular}{|c|c|c|c|c|c|c|}
\hline \multirow[t]{3}{*}{ Plant } & \multicolumn{6}{|c|}{ Organ of plant } \\
\hline & \multicolumn{2}{|c|}{ Buds } & \multicolumn{2}{|c|}{ Leaves } & \multicolumn{2}{|c|}{ Petioles } \\
\hline & Benzoic acid & Caffeic acid & Benzoic acid & $\begin{array}{c}\text { Caffeic } \\
\text { acid }\end{array}$ & Benzoic acid & Caffeic acid \\
\hline $\begin{array}{l}\text { Populus } \\
\text { nigra L. }\end{array}$ & $12-33$ & $\begin{array}{c}579 \pm 103.8 \\
t_{\text {def }}=5.58 \\
t_{S t}=2.78\end{array}$ & $3.9-29.4$ & $\begin{array}{c}19.8 \pm 1.92 \\
t_{\text {def }}=10.3 \\
t_{\mathrm{st}}=2.45\end{array}$ & $24.9-65.7$ & $\begin{array}{c}18.3 \pm 4.149 \\
t_{\text {def }}=4.41 \\
t_{s t}=2.57\end{array}$ \\
\hline $\begin{array}{l}\text { Populus } \\
\text { tremula L. }\end{array}$ & $58.2^{*}$ & $\begin{array}{c}37.2 \pm 14.2 \\
t_{\text {def }}=2.62 \\
t_{\mathrm{st}}=2.57\end{array}$ & BD & $19.8^{*}$ & BD & $8.7^{*}$ \\
\hline $\begin{array}{c}\text { Betula } \\
\text { pendula } \\
\text { Roth }\end{array}$ & BD & $\begin{array}{c}15.12 \pm 2.04 \\
t_{\text {def }}=7.4 \\
t_{\mathrm{st}}=2.78\end{array}$ & NA & NA & $\mathrm{BD}$ & $9.9^{*}$ \\
\hline
\end{tabular}

*Single samples. $\pm=S$ tandard deviation, $t_{\text {def }}=S$ tudent's calculated criterion, $t_{\mathrm{st}}=$ Student's $t$-test, The results were reliable for $t_{\text {def }}>t_{\mathrm{st}^{\prime}} B D$ was below the detection limit of the method $(<1.0 \mathrm{mg} / 100 \mathrm{~g}), \mathrm{NA}=\mathrm{Not}$ analyzed. 


\begin{tabular}{|c|c|c|c|c|c|c|}
\hline \multirow[t]{3}{*}{ Plant } & \multicolumn{6}{|c|}{ Organ of plant } \\
\hline & \multicolumn{2}{|c|}{ Buds } & \multicolumn{2}{|c|}{ Leaves } & \multicolumn{2}{|c|}{ Petioles } \\
\hline & Histidine & Phenylalanine & Histidine & Phenylalanine & Histidine & Phenylalanine \\
\hline $\begin{array}{l}\text { Populus } \\
\text { nigra L. }\end{array}$ & $\begin{array}{c}252.15 \pm 42.22 \\
t_{d e f}=5.97 \\
t_{s t}=3.18\end{array}$ & $\begin{array}{c}288 \pm 59.69 \\
t_{d e f}=4.83 \\
t_{s t}=3.18\end{array}$ & $\begin{array}{c}440 \pm 50.23 \\
t_{\text {def }}=8.77 \\
t_{S t}=2.78\end{array}$ & $\begin{array}{c}478.6 \pm 45.32 \\
t_{d e f}=10.56 \\
t_{s t}=2.78\end{array}$ & $\begin{array}{c}640.73 \pm 136.30 \\
t_{\text {def }}=4.70 \\
t_{s t}=3,18\end{array}$ & $\begin{array}{c}344.78 \pm 18.68 \\
t_{\text {def }}=18.46 \\
t_{S t}=3,18\end{array}$ \\
\hline $\begin{array}{c}\text { Populus } \\
\text { tremula } \\
\text { L. }\end{array}$ & $\begin{array}{c}202.05 \pm 25.05 \\
t_{d e f}=8.07 \\
t_{s t}=3.18\end{array}$ & $\begin{array}{c}399.15 \pm 16.35 \\
t_{d e f}=24.41 \\
t_{s t}=4.30\end{array}$ & $875.70^{*}$ & $632.40^{*}$ & $467.70^{*}$ & $352.50^{*}$ \\
\hline $\begin{array}{c}\text { Betula } \\
\text { pendula } \\
\text { Roth }\end{array}$ & $\begin{array}{c}297.45 \pm 19.3 \\
t_{d e f}=15.41 \\
t_{S t}=3.18\end{array}$ & $\begin{array}{c}2323.58 \pm 276.9 \\
t_{\text {def }}=8.39 \\
t_{S t}=3.18\end{array}$ & NA & NA & $180.90^{*}$ & $513.90^{*}$ \\
\hline
\end{tabular}

*Single samples. $\pm=$ Standard deviation, $t_{\text {def }}=$ Student's calculated criterion, $t_{\mathrm{st}}=$ Student's $t$-test, the results were reliable for $t_{\text {def }}>t_{\mathrm{st}^{\prime}}$ $\mathrm{NA}=$ Not analyzed.

the regions of Penza, Samara and Ulyanovsk. Heavier protein fractions were detected in the buds of Populus tremula and the propolis samples collected in the Krasnodar region. The results of the studies made it possible to suggest that the identified proteins of propolis samples are different types of propolis marker proteins. ${ }^{10}$

\section{Quantitative analysis}

\section{Flavonoids}

The quantitative content of flavonoids, determined spectrophotometrically, was $6.7 \%$ for the propolis collected in the Republic of Khakassia, 4.3\% for the Novosibirsk region, 4.7\% for the Altai region and 3.9\% for Krasnodar Territory (Sochi) which is average and sufficient for medical use. The studies of the alcohol extracts' spectra from propolis showed that, in all the cases, there is a main intense absorption maximum at the wavelength of 300-400 nm (flavanones) and "the shoulder" at the wavelength of 240-280 nm (flavanones and hydroxycinnamic acids). Comparable spectral characteristics have also been found out for the alcohol extracts from the buds of Populus sp. and Betula sp, which indicates a direct genetic connection in the flavonoid composition of the investigated group of substances. ${ }^{11}$

The quantitative content of phenolic compounds in the propolis of the Nizhny Novgorod region was 4.4\%-5.5\%. Flavones, flavones, flavonols, flavanols and anthocyanins have also been found out among them. ${ }^{12}$

The amount of routine in the investigated propolis samples from Ryazan, Nizhny Novgorod, Vologda, Voronezh region, the Republic of Adygea, Chuvashia, Udmurtia, Mari El and the Krasnodar region averaged $2.42 \%$ with variations from $0.05 \%$ to $4.5 \%$. The greatest amount of routine was found in the propolis collected in the Ryazan region (3.5\%-4.0\%). The content of quercetin was $4.92 \%$ on the average, with variations from
$0.7 \%$ to $14.97 \%$ in the samples, most of all in the propolis from the Ryazan region (8.34\%-14.97\%) and the Krasnodar region (9.3\%-12.75\%); the average of naringenin was $7.73 \%$ with variations from $4.2 \%$ to $12.9 \%$ in the samples, the largest amount was detected in the propolis from the Kursk region (9.1\%), the Republics of Udmurtia (9.9\%), Mari El (9,0\%), Chuvashia (8.8\%) and the Krasnodar region $(12.9 \%)$. The content of polyphenolic compounds was $12.23 \%$ on the average with fluctuations from $5.9 \%$ to $20.9 \%$, the largest amount was established for propolis from the Krasnodar region (20.9\%), the Republic of Adygea (19.8\%), the Kursk region $(16.5 \%)$ and the Altai Territory $(16.7 \%){ }^{13}$

For the analysis of propolis obtained from the buds of various species of the Populus genus, the methods for quantitative determination of the sum of hydroxycinnamic acids and flavonoids with the use of direct spectrophotometry of the propolis solution in comparison with the state standard sample of pinostrobin at the wavelength of $289 \mathrm{~nm}$ have been developed..$^{14}$ It has been established that the total absorption curve of the Ultraviolet (UV) spectrum of a typical propolis sample Populus sp. and state standard sample pinostrobin is due to the characteristic of the absorption of flavanones (pinostrobin): The main absorption maximum of the UV spectrum of the initial solutions is found in the range of $289 \mathrm{~nm}$ and after the formation of the complex with aluminum (III) chloride, a shift to the longwave region of the UV spectrum $(310 \mathrm{~nm})$ is observed. The character of absorption of the UV spectrum of propolis samples of Betula sp. and Populous tremula differs from those for Populus sp. by a more pronounced maximum or shoulder in the region of 300-330 nm. ${ }^{9}$

According to the State All-Union standard 28886-90 "Propolis. Specifications," one of the indicators of naturalness and quality of propolis is the total content 
of phenolic compounds. The mass fraction of phenolic compounds should not be $<25 \%$ in propolis. ${ }^{15}$

The total content of phenolic compounds of propolis from different collection regions varies significantly. The samples from the Perm region contained 26.22\% of phenolic compounds, from the Tyumen region contained $20.30 \%,{ }^{16}$ from the Orel region contained $34.1 \%$, from the Moscow region contained 46.4\%, ${ }^{17}$ from the Republic of Bashkortostan contained $54.06 \%$, from the Altai Territory contained $58.13 \%{ }^{18}$ and from the Republic of Tatarstan, phenolic compounds were represented by $34.5 \% .^{19}$

\section{Oxidability index}

To determine the quality of propolis samples, it is recommended to determine the degree of oxidation in the presence of the solution of potassium permanganate $0.1 \mathrm{~N}$. Hence, in the experiment to determine the quality of propolis of the Republic of Bashkortostan, the rate of decolorization of the potassium permanganate solution averaged $21.97 \mathrm{~s},{ }^{20,21}$ of the Orel region $7.5 \mathrm{~s}$ and of the Moscow region $18.5 \mathrm{~s},{ }^{17}$ which fits in the standard of no more than $22 \mathrm{~s}^{13}$

The results of the analysis have shown that, in the studied samples of propolis, there is the amount of oxidizable substances that meets the requirements of the State All-Union standard 28886-90: not less than 0.6 in $1 \mathrm{ml}$ of the oxidant solution per $1 \mathrm{mg}$ of propolis. The quantitative content of oxidizable substances in the propolis of the Oryol region was 2.10 in $1 \mathrm{ml}$ of the oxidizer solution per $1 \mathrm{mg}$ of propolis, in the propolis of the Moscow region, it was 2.15. ${ }^{17}$

\section{Minerals}

The quantitative content of microelements in the propolis samples from the Stavropol region was determined on the atomic absorption spectrophotometer "QUANTAFA." As a result, it was found out that the propolis contains the following microelements: iron $(1.42-0.42 \mathrm{mg} /$ $\mathrm{kg})$, manganese $(7.4-0.62 \mathrm{mg} / \mathrm{kg})$, zinc $(6.6-2.4 \mathrm{mg} / \mathrm{kg})$, copper $(0.14-0.32 \mathrm{mg} / \mathrm{kg})$, aluminum $(0.05-0.01 \mathrm{mg} /$ $\mathrm{kg}$ ) and chromium (0.01-0.02 mg/kg). The measurement of the mass concentration of anions (chlorides, sulfates and phosphates) and cations (sodium, calcium, potassium and magnesium) in the propolis samples was carried out by ion chromatography. The following ions were detected: anions-sulfates (1384-420 mg/kg), chlorides $(2.92-1.38 \mathrm{~g} / \mathrm{kg}$ ) and phosphates $(1042-24 \mathrm{mg} /$ $\mathrm{kg}$ ); cations-sodium (504-172 mg/kg); calcium (225$204.6 \mathrm{mg} / \mathrm{kg}$ ); magnesium (125.2-104.4 mg/kg); and potassium $(206-1.1 \mathrm{mg} / \mathrm{kg}$ ). Thus, during the analysis, it was revealed that zinc and manganese and chloride and sulfate ions predominate in the propolis samples. The samples did not reveal heavy metals, including cadmium, nickel and lead. ${ }^{22}$

Kaigorodova and Kartashova determined the mineral composition of propolis from the Perm region by the method of optical emission spectrometry with inductively coupled plasma on a Perkin Elmer 7000 RL instrument with the use of Merck IV multielement standard solution (23 elements). For the propolis obtained by the bees from the plants $P$. nigra and $P$. tremula, the content of the elements was as follows: calcium -701.00 and $616.80 \mathrm{mg} / \mathrm{kg}$; aluminum - 252.50 and $201.80 \mathrm{mg} / \mathrm{kg}$; iron - 403.90 and $258.90 \mathrm{mg} / \mathrm{kg}$; magnesium - 165.60 and $143.10 \mathrm{mg} / \mathrm{kg}$; potassium - 431.10 and $302.90 \mathrm{mg} /$ $\mathrm{kg}$; sodium - 203.60 and $249.10 \mathrm{mg} / \mathrm{kg}$; cobalt -1.76 and $1.40 \mathrm{mg} / \mathrm{kg}$; copper -11.32 and $8.17 \mathrm{mg} / \mathrm{kg}$; chromium -2.57 and $3.55 \mathrm{mg} / \mathrm{kg}$; nickel -6.51 and 5.33 $\mathrm{mg} / \mathrm{kg}$; manganese -15.51 and $10.65 \mathrm{mg} / \mathrm{kg}$ ); cadmium -0.22 and $0.166 \mathrm{mg} / \mathrm{kg}$; and zinc -94.18 and 16.10 $\mathrm{mg} / \mathrm{kg}$, respectively. ${ }^{23}$

\section{Microscopic analysis of propolis}

Propolis is also proposed to be analyzed microscopically to identify the source(s) of its origin using a specially developed technique. Babaeva et al. analyzed 12 samples of propolis and identified 20 pollen types. The pollen grains of the representatives of the Asteraceae family were observed most often. They have been registered in ten samples. Among the pollen of this plants' family, the pollen grains of the Ambrosia sp., Artemisia sp. and Centaurea sp. genera have been detected. The domination of the pollen spectra in the composition of Asteraceae species, as well as the detection of pollen grains in the plants of Cannabaceae, Dipsacaceae, Plumbaginaceae, Onagraceae and Polygonaceae families, has led the authors to assume that propolis production time is July-August. A similar conclusion was based on the presence of Tilia sp. pollen grain in the propolis from Bashkortostan. In addition to the plants blooming in late summer, in a lot of propolis samples, there was a recorded pollen of the trees blooming in early spring as follows: Betula sp. (six samples), Alnus sp. (one sample) and Pinus sp. (four samples). These plants are characterized by anemophilia and as a result, high pollen productivity, which determines the detection of single pollen grains in the spectra of different origin. In the propolis samples from the nonchernozem zone of Russia (Shatursky and Pushkin districts of the Moscow region), the spectrum was dominated by the pollen grains of the plants occurring in Central Europe. In this area, bees mostly visit plants of Helianthus sp., Centaurea sp., Solidago sp., Trifolium sp., Medicago sp., Onobrychis sp., 
Melilotus sp. and Fagopyrum sp. genera. In the propolis samples obtained from the Republic of Bashkortostan, Tilia $s p$. pollen dominated. A propolis sample from the Saratov region was characterized by a great number of pollen grains of the Ambrosia genus plants. A propolis sample from the Altai Republic contained pollen grains of the plants of Lamiaceae, Apiaceae and Asteraceae families in a small amount but a wide variety; therefore, it was not possible for the study's authors to identify the dominant pollen type. ${ }^{24}$

\section{Application of propolis in folk medicine}

In folk medicine, propolis is used to treat skin diseases, nonhealing wounds, gastric and duodenal ulcers, neuritis, migraine, pulmonary tuberculosis, bronchial asthma, rhinitis, eustachitis, influenza and dental and oral diseases. ${ }^{25}$ To do this, using a propolis extract, tincture is prepared and then, it is added to butter or milk. ${ }^{1}$ In colitis and gastrointestinal disease, folk medicine recommends taking propolis in its natural form by $0.5 \mathrm{~g}$ balls in the size of a pea, which must be chewed. ${ }^{26}$

\section{Pharmacological properties and application of propolis in scientific medicine}

\section{Antioxidant activity}

According to Korochkina and Vasiltsova's data, the antioxidant activity of $40 \%$ propolis alcohol extract was $18.94 \pm 0.50 \mu \mathrm{mol} / 1 \times 1$, that of $70 \%$ alcohol extract was $35.55 \pm 0.4650 \mu \mathrm{mol} / 1 \times \mathrm{m}$ and that of $96 \%$ alcohol extract was $57.36 \pm 0.66 \mu \mathrm{mol} / 1 \times \mathrm{min} .{ }^{27}$

At a daily dose of $20 \mathrm{mg} / \mathrm{kg}$, in the 14-day course of medication, propolis decreases the process of lipid peroxidation in acute total myocardial ischemia against the background of experimental hyperlipidemia, preserving the correlation relationships with the levels of serum atherogenicity index and the level of nonidentifiable activity and the lability coefficient of acid phosphatase in the myocardium of rats. Being applied in preparations, propolis maintains a high degree of positive correlation with the level of malondialdehyde in ischemic myocardium, as well as against the background of experimental hyperlipidemia. ${ }^{28}$

The use of propolis in modeling cerebral ischemia led to the correction of lipid peroxidation processes in erythrocytes and brain tissue: the content of peroxidation products decreased and the level of bio-antioxidants increased, which contributed to the stabilization of membranes and the prevention of their structural damage and dysfunction. The presence of oleic acid as well as flavonoids, which are components of the body's natural antioxidant system, can be of certain significance in the development of the antioxidant action of propolis.
Thus, in experimental cerebral ischemia, propolis has an antioxidant effect and can be recommended for the prevention and complex therapy of ischemic and hypoxic conditions. ${ }^{29}$

The molecular mechanisms of the antioxidant action of propolis bioflavonoids in prospermia have been evaluated. The use of propolis at a daily dose of $40 \mathrm{mg}$ for 3 months was accompanied by the normalization of ejaculate parameters, a decrease in the biomarkers of oxidative damage to proteins and sperm DNA, as well as the restoration of the sperm plasma antioxidant status. ${ }^{30}$ Suppositories with a propolis extract are provided for the integrated treatment and prevention of chronic inflammatory diseases of female genitalia as the main cause of infertility. ${ }^{31}$ Propolis powder is effective in the treatment of acne. Prescription of propolis preparations in patients with acne and gastrointestinal pathology contributes to the decrease in the activity of free radical oxidation processes. ${ }^{32}$

\section{Antimicrobial activity}

Propolis has a bactericidal effect on most of the tested microorganisms, in particular, on Gram-positive cocci (Micrococcus lysodeicticus, Staphylococcus aureus and Sarcina lutea) ${ }^{33,34}$ Gram-negative bacilli (Bacillus subtilis), Grampositive bacilli (Corynebacterium egui), as well as on some types of mold (Aspergillus ochraceus) and yeast (Saccharomyces cerevisiae). ${ }^{33}$

It has been established that suppositories with succinic acid and propolis in 1:100 dilution have a non-selective antimicrobial effect against Gram-positive and Gramnegative bacteria and yeast-like fungi. ${ }^{35}$

The composition based on nanostructured "core-shell" systems, which is an aqueous dispersion of nanoscale flavonoid "cores" obtained from natural propolis and stabilized by a polyelectrolyte "shell," can be effectively and safely used in complex therapy in the treatment of microbial eczema in the acute phase of dermatosis. ${ }^{36}$

The apisupplement of drone larvae and of finely ground propolis after sublimation vacuum drying, possesses high antituberculosis and immunomodulating properties, which, being non-toxic, stimulate T-cell immunity reactions and antibody producers of the spleen. ${ }^{37}$

Propolis extract has a direct antiviral effect against influenza virus. ${ }^{38}$

\section{Antiulcer action}

Adding propolis to the triple eradication therapy for Helicobacter pylori, including patients with clarithromycin-resistant Helicobacter pylori strains, in addition to increasing the effectiveness of eradication, reduces the frequency of adverse events and improves the quality of life. ${ }^{39,40}$ 
Propolis has a pronounced gastroprotective effect in rat gastric acetate ulcer, caused mainly by the choline and serotonin-active actions. Among the amino acids in honey products, tryptophan and phenylalanine have been detected in significant concentrations. They are precursors of the synthesis of serotonin and catecholamines involved in the motor function regulation of the stomach. $^{41}$

A promising object for the treatment of gastric ulcer and duodenum is a combined natural preparation based on a phenolic hydrophobic extract of propolis, powdered honey and plantaglucid. As a result of a screening study on a model of acute prednisone ulcer in rats, the presence of a pronounced anti-ulcer effect has been detected; it is most often observed at a dose of $100 \mathrm{mg} /$ $\mathrm{kg}$ of the experimental animals. ${ }^{42}$

\section{Periodontitis treatment}

The use of propolis electrophoresis causes a rapid and pronounced relief of the main clinical manifestations of chronic generalized periodontitis. After a set of therapeutic measures, the depth of the periodontal pocket decreased from $4.6 \mathrm{~mm}$ to $4 \mathrm{~mm}$. The X-ray examination showed a partial restoration of the alveolar bone structure. ${ }^{43}$ Impulse phoresis ${ }^{44}$ and phonophoresis with propolis $^{45}$ are also effective.

\section{Application administration}

The applicator on the basis of propolis consisting of a layered material has been worked out. The inner layer of the applicator, intended for skin interaction with a diseased part of the body, was impregnated with a medicinal composition containing propolis. The impregnation with $100 \%$ propolis is carried out by bees during their activity. For that, the applicator is placed in the hive at the distance of $0.5-1 \mathrm{~cm}$ from the honeycomb frames so that the inner layer of the applicator would be facing them. The applicator can be used in the treatment of the diseases of the musculoskeletal system, such as osteochondrosis, radiculitis, arthritis, neurology, myalgia and inflammatory diseases of the joints, as well as in the treatment of skin lesions. ${ }^{46}$

The application administration of Koletex-SP-1 wipes with propolis (the content of propolis on the napkin surface is $4 \mathrm{mg} / \mathrm{cm}^{2}$ ) for the prevention of local radiation reactions ensures their later development and a significant reduction in their severity. In the treatment of local radiation reactions, the application of propolis wipes significantly improves the life of patients. This treatment is well tolerated and side effects are rare. They are manifested in the development of allergic reactions in case of individual intolerance to propolis. ${ }^{47}$

\section{Antidiabetic properties}

In animals with alloxan diabetes, the administration of propolis prevents deepening of carbohydrate metabolism disorder, improves its regulation, restores glycolysis and glycogen formation in the liver and increases the reactivity of insulin target receptors. ${ }^{48}$ The administration also normalizes lipid and protein-nucleic acid metabolism and activates anabolic processes in pancreatic and liver tissues. These factors are manifested by the increase of nucleic acids and protein in the content of tissues. ${ }^{49}$ The level of thiobarbituric acid-active products, diene conjugates, erythrocyte hemolysis, as well as the total antioxidant activity in the animals with alloxan diabetes, is restored under the influence of propolis and the number of molecules of the average weight significantly decreases, which makes it possible to judge about its ability to reduce the general intoxication of the experimental animals. ${ }^{50}$

In people with Type I diabetes, propolis causes an increase in the level of CD3+, CD4+ and CD20+ cells; an increase in serum immunoglobulin $\mathrm{A}(\mathrm{IgA})$ and $\mathrm{IgG}$; and a decrease in serum $\operatorname{IgM}$, as well as a decrease in the level of autoantibodies to insulin autoantibody and islet cell antibody glutamic acid decarboxylase, most pronounced in patients with a moderately severe course and the duration of hyperglycemia not longer than 5 years. This effect makes it possible to use propolis in the treatment of Type 1 diabetes. ${ }^{51}$

\section{Anti-edemic effect}

The inhalation course of royal jelly and propolis wateralcohol suspension in modeling adrenal pulmonary edema in rats, helps to reduce the formation of endogenous intoxication, i.e., to reduce the release of endogenous toxins into the blood from the lung tissue; to reduce the activity of lipid peroxidation; to restore the biologic system of endogenous toxins; to increase the sorption capacity of erythrocytes and concentrations of albumin, very low-density lipoproteins and low-density lipoproteins; to increase the concentration of total protein and fibrinogen; and to normalize the ratio of phospholipid fractions and proteins. After inhalation, there is a decrease in the severity of endogenous intoxication, which is characterized by a decrease in the content of medium-mass molecules in the plasma and erythrocytes and the restoration of the functional activity of liver and kidneys. ${ }^{52}$

\section{Antihypoxic and detoxifying effects}

It has been established that suppositories with glutamic acid and propolis extract increase patients' lifetime with hypoxia of various origins. The survival rate of rats 
under the conditions of acute hyperbaric hypoxia significantly increases compared with the control group treated with isotonic sodium chloride solution..$^{53}$

The use of propolis extract as detoxicant normalizes the biochemical status of rats when toxic elements enter the body. ${ }^{54}$

\section{Antiplatelet and hemostatic effects}

The study of the effect of propolis on platelet aggregation was carried out in vitro. Adenosine diphosphate in the concentration of $5 \mu \mathrm{g} / \mathrm{ml}$ and collagen in the concentration of $20 \mathrm{mg} / \mathrm{ml}$ were used as aggregation inductors. The antiplatelet properties of propolis were studied in the concentrations of $10^{-3}, 10^{-5}, 10^{-7}$ and $10^{-9} \mathrm{~g} / \mathrm{ml}$. The solutions of propolis in the studied concentrations effectively reduced the aggregation function of blood plates. ${ }^{55}$

Under the conditions of experimental hemorrhagic anemia in rats, the effect of suppositories containing albumin and a propolis extract has been studied. Restoration of the ceruloplasmin level after the recovery therapy in case of blood loss has been shown. On the $14^{\text {th }}$ day, the hemoglobin level increased to $80 \%-88 \% .{ }^{56}$

\section{Propolis dosage forms}

Modern Russian medicines based on propolis are as follows: "Propolis tincture," produced by 18 manufacturers; Proposol spray for local use. Propolis is included into homeopathic medicines: rectal suppositories "Propolis DN," oral drops "Propolan Edas-150" and "Propolis homeopathic." 57

A number of patents for preparations containing propolis have also been worked out: rectal suppositories with propolis; ${ }^{58}$ rectal suppositories with nicotinic acid and propolis extract ${ }^{59}$ suppositories with dibunol and propolis extract for the treatment of gynecological inflammatory diseases; ${ }^{60}$ suppositories with the extract of large wax moth larvae and propolis extract for the treatment of gynecological diseases; ${ }^{61}$ ointment with ionol and propolis extract for the treatment of inflammatory diseases in the field of gynecology; ${ }^{62}$ wound healing propolis; ${ }^{63}$ propolis ointment; ${ }^{64}$ ointment for the treatment of burn diseases with albumin and propolis extract ${ }^{65}$ oral care compositions containing propolis; ${ }^{66}$ a glutamic acid and propolis extract, having nootropic activity; ${ }^{67}$ a remedy with liposomes containing amber acid and propolis extract, which has detoxification and antioxidant activities; ${ }^{68}$ and a medicinal product containing propolis extract, ascorbic acid and sugar. ${ }^{69}$

In addition, methods of production of aqueous, ${ }^{70-72}$ ethanolic ${ }^{73}$ and thick extracts, ${ }^{747}$ as well as propolis oil, have been developed. ${ }^{76}$

\section{Application of propolis in food industry}

In food industry, propolis is used to enrich nutritional formulations with essential substances that are necessary for proper functioning of the body. In Russia, fifty biologically active additives containing propolis have been registered. ${ }^{77}$

The antimicrobial action of propolis is used in food production because propolis preparations contribute to the increase in shelf life without using any preservatives and antibiotics. ${ }^{78}$

For example, processing natural shells of semi-smoked sausages with alcoholic propolis tincture diluted 1:10 does not adversely affect the organoleptic and physicochemical parameters and improves microbiological characteristics, which suggests the appropriate use of this medicament in the production technology of meat products in order to create a safe product that preserves its consumer properties during the tested shelf life. ${ }^{79}$

\section{Household and economic use}

A lot of products with the use of propolis are manufactured in Russia: gels for washing, deodorants, protective gel balms for face, aftershave products, shampoos, cosmetic creams, lotions, toothpastes, hygienic lipsticks and soap. ${ }^{78}$

Pencils and lacquer ware containing propolis and amber make it possible to create protective films that impede the growth and development of the fungi Aspergillus niger and Penicillium culmorum and bacteria Bacillus sp., often found on the surface of domestic and industrial premises. $^{80}$

In aerosol application of 5\% water-alcohol emulsion, the total microbial number of air decreased 4.5 times in $30 \mathrm{~min}$ and 5.2 times in $60 \mathrm{~min}$ after spraying the medicament. $^{81}$

As a natural bactericidal agent for fish farm tanks, an aerosol of aqueous microsuspension of pine resin and propolis obtained by ultrasonic spraying has been proposed. It is effective against Candida sp., Micrococcus sp., Moraxella sp., Nitrobacter sp., Bacillus sp. and Aeromonas sp. $^{82}$

\section{Insecticidal application of propolis}

Ecologically safe and harmless to bees, the medicament "Topol-B1," created on the basis of propolis, protects plants from pests more effectively than chemical insecticides, the application of which is undesirable. For many years, many berry and vegetable crops have been tested such as Fragaria sp., Rosa sp., Lonicera edulis, Solanum tuberosum and Brassica oleracea; the medicament has proved to be an effective against such pests as Curculionidae sp., Rhagoletis alternata, Agrilus cuprescens, Agrilus coeru- 
leus, Megastigmus aculeatus, Cetonia aurata, Pieris brassicae and Leptinotarsa decemlineata. The efficacy of the medicament against insects belonging to different systematic groups indicates a great prospect of its use in plant protection. ${ }^{83}$

\section{Application of propolis in veterinary medicine}

Propolis is also used in veterinary medicine. ${ }^{84}$ For example, propolis is used for acute catarrhal-purulent endometritis ${ }^{85}$ and cow mastitis. ${ }^{86}$ In combination with probiotics, it is used to increase the level of vitamins in cow milk. ${ }^{87}$ Water-alcohol propolis emulsion in the form of aerosol is used in case of bronchopneumonia in calves ${ }^{88}$ and piglets. ${ }^{89}$ Propolis is effective for improving the immunity of horses ${ }^{90}$ and broiler birds. ${ }^{91}$

\section{CONCLUSION}

Thus, propolis is the most valuable biologically active product of beekeeping. It has a wide range of pharmacological activity due to a number of chemical compounds and is used in Russia.

The studies of the authors and the obtained results in this review are aimed at identifying the biochemical characteristics of the sources of propolis and establishing the markers of its botanical and geographical origin. The functional properties of propolis obtained by bees from different plant species are determined by definitive biologically active substances, which should be taken into consideration while determining the appropriate applications of a particular propolis type. This kind of research is valuable for its standardization.

\section{CONFLICT OF INTEREST}

The authors declare no conflict of interest.

\section{REFERENCES}

1. Soloveva AV. Propolis, Wax, Mummy, Bee Venom. Moscow: AST; St. Petersburg: Astrel-SPb. 2007.

2. Shelestova VV, Kovaleva EL, Bunyatyan ND, Nikolaeva OB. Comparative evaluation of the quality assurance requirements for pharmaceutical substance Propolis. Int J Appl Fundam Res. 2016;2:48-52.

3. Suhanova LV, Kanarskiy AV. Propolis as a biologically active product. Bull Kazan Technol Univ. 2014;17:198-203.

4. Kaygorodov RV, Suvorova SA. Biochemical features of plant sources of propolis of the moderate natural area. Bull Perm Univ. 2013;3:65-8.

5. Popova MP, Bankova VS, Bogdanov S, Tsvetkova I, Naydenski C, Marcazzan $\mathrm{GL}$, et al. Chemical characteristics of poplar type propolis of different geographic origin. Apidologie. 2007;38(3):306-11.

6. Popova M, Trusheva B, Khismatullin R, Gavrilova N, Legotkina G, Lyapunov $J$, et al. The triple botanical origin of Russian propolis from the Perm region, its phenolic content and antimicrobial activity. Natl Prod Commun. 2013;8(5):617-20.

7. Oleshko LN, Belonogova VD, Petuhova V, Chubun Y. Chemical research of dense extract of propolis. Materials of the Jubilee Interuniversity ScientificPractical Conference of the Faculty Dedicated to the $275^{\text {th }}$ Anniversary of the City of Perm and the $80^{\text {th }}$ Anniversary of Pharmaceutical Education in the Urals. Perm. 1998;163.

8. Simonyan EV. The study of the chemical composition of propolis and the theoretical justification for applying it in complex with derivatives of carboxylic acids. Int J Exp Educ. 2016;5:309-13.

9. Braslavskiy NV. Standardization of propolis preparations. Questions Biol Med Pharm Chem. 2013;5:32.

10. Braslavskiy NV, Shatalaev IF. Studies on the standardization of raw materials and propolis tinctures. Development, research and marketing of new pharmaceutical products: A collection of scientific papers. Pyatigorsk Med Pharm Institute. 2013;68:233-4.

11. Pogrebnyak DI, Bortnikov SV. Study of flavonoid composition of bee propolis. Natl Math Sci Modern World. 2012;1:125-9.

12. Ivaschenko MN, Samodelkin AG, Sitnikova NO. The study of the phenolic composition of propolis collected in the territory of the Nizhny Novgorod region. Modern Problems of Science and Education. 2014;6:1441.

13. Vahonina EA, Budnikova NV, Mitrofanov DV, Stepantseva GK. Flavonoid compounds of propolis: Composition and properties. Apitherapy Today: Materials of the XVIII All-Russian Scientific Conference. 2016:78-85.

14. Braslavsky VB, Kurkin VA. Poplar (Populus) and propolis: Standardization of raw materials and preparations. Pharmacy 2009;4:53-6.

15. State Standard 28886-90 "Propolis". Group C52. Interstate Standard. Specifications Propolis. Moscow: IPK Publishing House of Standards. 1990.

16. Kaygorodov RV, Malkova OA, Kaygorodova YV. The total content of phenolic compounds in propolis is of different botanical and geographical origin. Eurasian Union Sci. 2015;5(7):17-8.

17. Babaeva EY, Danilina EA, Dzhavakhyan MA. Studying of some physical and chemical parameters of propolis. Questions Biol Med Pharm Chem. 2015;9:25-9.

18. Kroer DV, Pototskaya YV, Yakushkin IV, Dovgan NB. Comparative veterinary and sanitary assessment of propolis and pollen obtained in different geographical zones. Science and Education in the Life of Modern Society: A Collection of Scientific Papers on the Materials of the International Scientific and Practical Conference. Tambov: 000 "Consulting Company Yukom". 2015;6:75-8.

19. Merkureva GY, Kamaeva SS. Researches on development of medicines with beekeeping products. Health - A Basis of Human Potential: Problems and Ways of Their Decision. 2014;9:967-8.

20. Dovgan NB, Sutulo AV, Timoshenko VA. Characteristics of methods for quality control and natural propolis. Bull Sci Conf. 2016;5(4):106-7.

21. Sutulo AV, Dovgan NB, Timoshenko VA. Evaluation of methods for identification of fake propolis. Sci Almanac. 2016;5(3):445-7.

22. Bryikalov AV, Tokareva NA, Belik EV. Research of quantity of the minerals which are contained in propolis. Basic Res. 2004;4:46.

23. Kaigorodova RV, Kartashova IN. Dynamics of mineral composition of propolis at its industrial processing. Bull Perm Univ Series Biol. 2016;2:102-8.

24. Babaeva EY, Danilina EA, Vandyishev VV, Severova EE. Development of a methodology for palynomorphological analysis of propolis. Bull Russian Univ Peoples Friendship Series Med. 2012;3:89-94.

25. Neumyivakin IP. Propolis. Myths and Reality. Moscow. 2005.

26. Sinyakov AF. Great Honey Therapy. Moscow: Eksmo-Press. 2000.

27. Korochkina PC, Vasiltsova IV. Antioxidant status of propolis and bee pollock. Actual problems of the agro-industrial complex: A collection of works of the scientific-practical conference of teachers, students, undergraduates and graduate students, dedicated to the $80^{\text {th }}$ Anniversary of the Novosibirsk State Agrarian University (Novosibirsk, November 7-11, 2016): Agricultural Sciences. Biological Sciences. Vet Sci. 2016;348-51.

28. Terton NV, Makarova VG, Yakusheva EN. Effect of propolis preparations on the lipid profile of blood in the experiment. Apither Today 2002;90-3.

29. Uzbekova DG. Effect of propolis on the state of lipid peroxidation and antioxidant protection in experimental cerebral ischemia. Apither Today. 2008;33-5.

30. Galimov SN, Pavlov VN, Galimova EF. Influence of bioflavonoids of propolis on the antioxidant potential of the ejaculate and oxidative damage of the sperm DNA. Androl Genital Surg. 2013;4:65-8.

31. Shikova JV, Lichoded VA, Radutnyj VN, Epifanova AV, Petrova VV, Shikov NA. Substantiation of application of products of beekeeping in gynecologic practice. Bashkir State Med Univ Ufa. 2012;4:52-4. 
32. Golovach NA, Ermoshina NP. Preparations in complex treatment of patients with vulgar acne. Joint Med J. 2007;1:47-8.

33. Golovach NA. Biochemical indicators in the evaluation of the effectiveness of pergium, propolis in the complex treatment of patients with acne. Apitherapy Today: Materials of the XVIII All-Russian Scientific Conference. 2016;17-20.

34. Maklakova EE, Moreva LY. Bactericidal action of propolis on different types of microorganisms. Apitherapy today: Materials of the $13^{\text {th }}$ All-Russian Scientific and Practical Conference. 2008;164-9.

35. Danilina EA, Kravtsov EG, Babaeva EY. Study of the antimicrobial activity of propolis. Bull Russian Univ Peoples Friendship Med. 2014;4:68-73.

36. Simonyan EV, Shikova YV, Likhoded VA, Grigoryeva GP, Ermolaev AD, Chernov AV, et al. Studying pharmacological suppositories with succinic acid and propolis extract. Bull South Ural State Univ Series Educ Healthc Serv Physical Educ. 2014;14(3):61-5.

37. Schnaider DA, Utz SR, Zayarskiy DA, Gus'kova OP, Gorokhovskiy AV. The first clinical experience of nanostructured propolis usage in treatment of patients with microbial eczema. Saratov J Med Sci Res. 2016;12(3):500-4.

38. Prohoda IA. Investigation of the quality of apipreparations from drone larvae and propolis and their use in immunomodulatory products. Fundam Appl Res Coop Sector Econ. 2008;4:139-41.

39. Epifanova AV, Shikova YV, Lihoded VA, Bahtiyarova SB, Zaripov RA. Study of antiviral activity of extracts of propolis and larvae of large wax moth. Apitherapy Today: materials of the XVII All-Russian Scientific Conference. 2014;39-42.

40. Dubtsova EA, Kasyanenko VI, Komissarenko IA, Belousova NL. Alternative methods of eradication. Helicobacter pylori. Gastroenterol St Petersburg. 2010;4:9.

41. Lazebnik LB, Belousova NL, Bordin DS, Miheeva OM, Dubtsova EA, Vorobeva NN, et al. The resistance of Helicobacter pylori to clarithromycin in Moscow and propolis as a means of increasing the effectiveness of eradication. Exp Clin Gastroenterol. 2012;8:10-4

42. Lychkova AE, Dubtsova EN, Kasyanenko VI, Puzikov AM. Gastroprotective effect of propolis and pollen. Exp Clin Gastroenterol. 2014;104:29-31.

43. Bogdan NS, Tihonov Al. Pharmacological study of a new combined antiulcer medicament proplantmed based on the phenolic hydrophobic extract of propolis. Recipe. 2016;4:456-62.

44. Haybullina RR, Gilmutdinova LT, Gerasimova LP, Haybullina ZR. Restorative treatment of chronic generalized periodontitis with the use of propolis electrophoresis. Int J Exp Educ. 2012;9:75-7.

45. Gilmutdinova LT, Haybullina RR, Gerasimova LP, Haybullina ZR. Impulsophoresis with propolis in the treatment of chronic generalized periodontitis. Modern High Technol. 2012;9:70-2.

46. Haybullina RR, Gilmutdinova LT, Gerasimova LP, Haybullina ZR. Application of phonophoresis with propolis at the stages of rehabilitation of patients with chronic generalized periodontitis. Modern High Technol. 2012;9:72-5.

47. Petrovskiy VP, Petrovskiy PI. Way of Production of Fixed Petrovsky P.I. Applicator on the Basis of Propolis. Invention Patent. RUS 2218940. 2002.

48. Polyakov PY, Byichenkov OA, Oltarzhevskaya ND, Korovina MA. Application of propolis with napkins "Koleteks" for the prevention and treatment of local radiation reactions. Effective Pharmacother. 2010;21:62-6.

49. Vasilenko YK, Zhuravleva AN. Impact of propolis on metabolic processes in experimental diabetes mellitus. Achievements, Problems, Perspectives of Pharmaceutical Science and Practice: Materials of the Regional Scientific and Practical Conference. Kursk: KSMU. 2006;339-42.

50. Vasilenko YK, Zhuravleva AN. Experimental substantiation of the use of apilac and propolis as an additional therapy for diabetes mellitus. Development, Research and Marketing of New Pharmaceutical Products: A Collection of Scientific Papers.. Pyatigorsk State Pharmaceutical Academy. 2007;62:455-7.

51. Vasilenko YK, Zhuravleva AN. The metabolic activity of apiculture products - Apilac and propolis. Man and Medicine: Abstracts of the $15^{\text {th }}$ Russian National Congress. 2008;14-18:598.

52. Vasilenko YK, Zhuravleva AN. Study of the metabolic activity of apilac and propolis. Pharmacy. 2010;2:45-8.

53. Magomedova ZS. Natural immunomodulators (propolis and apilac) in the complex treatment of type 1 diabetes mellitus. The Collection of Scientific Works of the Dagestan State Medical Academy is 75 Years Old. Makhachkala. 2007;283-5.
54. Kopyilova CB, Anashkina AA, Starateleva YA. Influence of the medicament "Apingalin" on some indices of endogenous intoxication with pulmonary edema in rats. Bull Nizhny Novgorod State Univ NI Lobachevsky. 2010;2:532-

55. Simonian EV, Shikova YV. Study adaptogenic effect of suppositories comprising glutamic acid and propolis extract. Med News North Caucasus. 2014;9:258-61.

56. Vasiltsova IV, Bokova TI. Effect of Propolis Extract on the Biochemical Parameters of Rat Blood. Ecology, Environment and Human Health: XXI Century Collection of Articles on the Materials of the II International Scientific and Practical Conference. 2016;23-9.

57. Ivashchenko MN, Samodelkin AG. Effect of propolis on platelet aggregation. Fundam Res. 2014;12:2146-9.

58. Simonyan EV, Shikova YV, Osikov MV, Saedgalina OT, Grigoreva GP, Yumaguzhina AT. Substantiation of structure, technology development and research of the pharmacological properties of the rectal suppositories containing albumin and propolis extract. Fundam Res. 2014;12:348-51.

59. State Register of Medicines. Available from: http://www.grls.rosminzdrav.ru/ default.aspx.

60. Ionova SA, Novoselova EA, Polunina EE. Rectal Suppositories with Propolis. Invention Patent. RUS 2207138. 2002.

61. Shikova YV, Lihoded VA, Simonyan EV, Yumaguzhina AT, Klimantova MS, Neves DaSilva AG, et al. Rectal Suppositories with Nicotinic Acid and Propolis Extract. Invention Patent. RUS 253724; 2013.

62. Shikova YV, Lihoded VA, Bahtiyarova SB, Shikov AN, Prusakov EV, Zaynullina ED, et al. Suppositories with Dibunol and Propolis Extract for the Treatment of Gynecological Inflammatory Diseases. Invention Patent: RUS 2249448. 2003.

63. Bahtiyarova SB, Shikova YV, Zaripov RA, Lihoded VA, Shikov AN, Lihoded TA, et al. Suppositories with Extract of Larvae of Large Wax Moth and Extract of Propolis for the Treatment of Gynecological Diseases. Invention Patent: RUS 2429867. 2010.

64. Shikova YV, Lihoded VA, Melnikov MV, Bahtiyarova SB, Zaripov RA, Gnezdin AP, et al. Ointment with lonol and Propolis Extract for the Treatment of Inflammatory Diseases in Gynecology. Invention Patent: RUS 2372093. 2008.

65. Nigmatullin TG, Lukmanova KA, Gizzatullina FZ. Wound Healing Coating with Propolis. Invention Patent: RUS 2231368. 2002.

66. Elnatanova MI, Krupennikova NA, Surkova LN, Shamanina EM, Morugina LV, Biktimirova IO. Ointment with Propolis. Invention Patent: RUS 2135159. 1997.

67. Shikova YV, Lihoded VA, Speranskiy VV, Bahtiyarova SB, Zaripov RA, Gnezdin AP, et al. Ointment for Treatment of Burn Diseases with Albumin and Propolis Extract. Invention Patent: RUS 2381804. 2008.

68. Fetissova N, Blanvale K, Lamber P. Compositions for Oral Care Containing Propolis. Invention Patent: RUS 2380084. 2006.

69. Shikova YV, Lihoded VA, Simonyan EV, Yumaguzhina AT, Klimantova MS, Neves DaSilva AG, et al. Medicament with Glutamic Acid and Propolis Extract, which has Nootropic Activity. Invention Patent: RUS 2538636. 2013.

70. Shikova YV, Simonyan EV, Lihoded VA, Ermolaev AD, Chernov AV, Grigoreva GP, et al. Medicament with liposomes containing succinic acid and propolis extract with detoxification and antioxidant activity. Invention Patent: RUS 256159. 2014.

71. Zabolotnyiy VA, Voevodin YN, Serebryakova OV, Suprun OV, Komissarenko EP. Medication with Propolis Extract, Ascorbic Acid and Sugar. Invention Patent. RUS 2109514. 1998.

72. Sazhiev RG, Tokarev IN. A Process for Preparing an Aqueous Extract of Propolis. Invention Patent: RUS 2303988. 2005.

73. Serzhantov GI. A Process for Preparing an Aqueous Extract of Propolis. Invention Patent. RUS 2402923. 2009.

74. Hismatullin RG. A Process for Preparing an Aqueous Extract of Propolis A-P-V. Invention Patent: RUS 2185181. 2001

75. Mandryika EA, Shapovalov GA, Evtihov PN, Pavlenko VN, Schitikov ES, Kulikov VA. Method for Obtaining an Extract of Propolis Alcohol. Invention Patent. RUS 2073519. 2009.

76. Hismatullin RG. A Method for Receiving Extract of Propolis thick "Pegus". Invention Patent: RUS 2182485. 2001. 
77. Milyakov GV, Blinova OA, Oleshko GI, Yusupova SD. Method for Obtaining a thick Extract of Propolis and a Medicament Based on it. Invention Patent: RUS 2240811. 2002.

78. Akushev IA, Narkevich VV, Nasyirov HM. Method for Obtaining Propolis Oil. Invention Patent: RUS 2143914. 1997.

79. Registers of Russian Consumer Supervision and Sanitary-Epidemiological Service of Russia. 2017. Available from: http://fp.crc.ru/.

80. Bronnikova VV. Food products with extracts of propolis. Fundam Appl Res Coop Sector Econ. 2016;1:106-10.

81. Pribyitova OS, Pribyitov IV, Pershina EI. Propolis as a factor ensuring the prolongation of the shelf life of sausages. Technol Technol Food Prod. 2014;2:66-70.

82. Akopyan VB, Bambura MV, Afonin AV, Filatova VA. Antimicrobial protective coatings with amber and propolis. Izvestiya Moscow State Tech Univ MAMI. 2012;4:262-9

83. Kondakova IA, Zlobin PA, Vologzhanina EA, Lgova IP. Study of the effect of propolis preparation on microbial air saturation. Bull Fsbei HPE RGATU. 2013;2:24-6.

84. Bambura MV, Aldoshina El. Investigation of the bactericidal properties of suspensions of resinous substances. Theses of the Scientific Conference of Students and young Scientists of MGUEE. 2011;162.

85. Boldyirev MI, Kolesnikov SA, Tihonov GY, Boldyireva SA. Repellent Preparation Topol-B1 for the Protection of Crops Against Pests. Patent No 2366180. 2009.

86. Gosmanov RG, Galiullin AK. Scientific basis development of propolis - Made medicaments. Sci Notes Kazan State Acad Vet Med Bauman. 2013;216:10610.
87. Osipova NI. Suppositories with propolis in acute catarrhal-purulent endometritis in cows (farms in the Ulyanovsk region). Vet Med Abstract J. 2004;2:504.

88. Hazipov RB. Recovery of suppressor reactions with propolis preparations in mastitis of cows. Apitherapy today. Materials of the International Scientific and Practical Conference on Apitherapy. 2002;79-80.

89. Fajzullin IM, Mannapova RT. Probitik and propolis for vitamin level increase in cow's milk. Vestnik BSAU. 2011;3:40-5.

90. Osipova NI. Therapeutic and prophylactic effectiveness of aerosol application of water-alcohol emulsion of propolis in bronchopneumonia of calves. Vet Med Abstract J. 2011;1.

91. Pozov SA, Marutyants NG. The effectiveness of propolis in bronchopneumonia in piglets. Actual problems of invasive, infectious and non-contagious pathology of animals. Materials of the International Scientific and Practical Conference dedicated to the $100^{\text {th }}$ Anniversary of the Birth of Professor Sergei Nikolaevich Nikolsky. 2003;264-5.

92. Mannapova RT, Shagivaleev AD. Correction of the immune status of horses with zeolites and propolis. Apitherapy today - With a biological pharmacy bees in the twenty-first century. Materials of the II International Scientific and Practical Conference on Apitherapy: 70 years of the Bashkir State Agrarian University. Bashkir State Agrarian University. 2000;266-8.

93. Shayhulov RR, Mannapova RT. The immune status of broiler birds and its correction by propolis and zeolites. Apitherapy today - With a biological pharmacy bees in the twenty-first century. Materials of the II International Scientific and Practical Conference on Apitherapy: 70 years of the Bashkir State Agrarian University. Bashkir State Agrarian University. 2000;443-4.

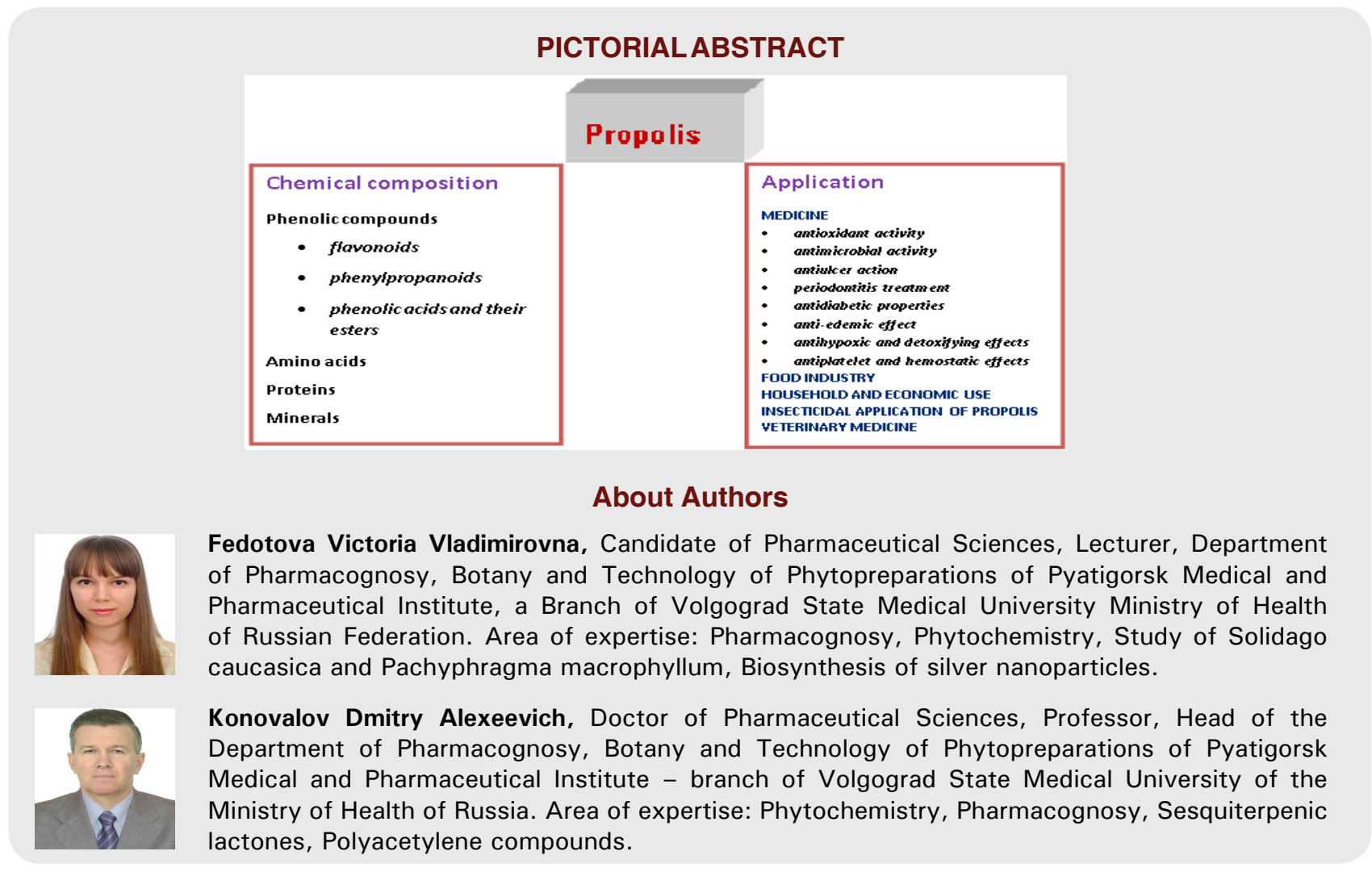

Cite this article: Fedotova VV, Konovalov DA. Propolis Research in Russia. Indian J of Pharmaceutical Education and Research. 2019;53(4s):s500-s509. 